\title{
STARZY PILOCI NA MOŚCIE, CZYLI DYSKRETNY UROK ALTERNACJI
}

\begin{abstract}
Słowa kluczowe: język polski jako obcy, alternacje (oboczności) morfonologiczne, fleksja, słowotwórstwo, świadomość glottodydaktyczna

Streszczenie. Język polski niesłusznie uchodzi za trudny, skomplikowane natomiast wydawać się mogą alternacje morfonologiczne, które występują w odmianie czasowników, rzeczowników, przymiotników, liczebników, zaimków i imiesłowów, w stopniowaniu, a także w słowotwórstwie. Artykuł pokazuje, iż do uporządkowania z pozoru chaotycznego świata polskich alternacji wystarczy kilka prostych reguł. Ucząc języka polskiego jako obcego, warto wprowadzać te reguły krok po kroku już na początkowym etapie nauki. Warto pamiętać, że odpowiednio zaprezentowane przykłady mówią czasem więcej niż długie komentarze metajęzykowe. Przy takim podejściu liczne formy gramatyczne nie jawią się jako ocean wyjątków, lecz jako sieci powiązań, które da się opanować.
\end{abstract}

\section{WPROWADZENIE}

Agata Bisko w przewodniku kulturoznawczym po współczesnej Polsce tak charakteryzuje polszczyznę:

(...) trudna do opanowania gramatyka: siedem przypadków, odmiana czasowników, trzy rodzaje i rozbudowana, bogata frazeologia. (...) To oraz wiele innych właściwości języka polskiego, których nie sposób tu nawet zarysować, sprawia, że mówi się często, przynajmniej w Polsce, że jest to jeden z najtrudniejszych na świecie języków do nauczenia.

(Bisko 2014, s. 44)

Pogląd, iż polski należy do języków trudnych, spotyka się niestety nie tylko w książkach popularnonaukowych, lecz także w podręcznikach, wspomagających naukę polskiego jako obcego. Podejście takie jest nie tylko fałszywe; jest też mało przydatne w glottodydaktyce. Zamiast wmawiać dorosłym, uczącym się polskie-

*liliana.madelska@univie.ac.at, Uniwersytet Wiedeński, Instytut Slawistyki, Spitalgasse 2-4, Hof 3, 1090 Wiedeń, Austria. 
go, że podejmują się niewykonalnego zadania, warto im to zadanie ułatwiać. Niniejszy artykuł ma na celu przedstawienie przynajmniej kilku sposobów na deegzotyzację polszczyzny - demonstrujemy tu krok po kroku, jak można oswoić ten z pozoru trudny język i ułatwiać opanowanie gramatyki, między innymi poprzez porównanie alternacji (oboczności, wymian) morfonologicznych w polskim i w niemieckim. Wychodzimy przy tym z założenia, że glottodydaktyk powinien nie tylko znać język, którego uczy, ale powinien umieć popatrzyć na ten język z perspektywy ucznia, tłumacząc nie tylko, czego się uczyć, ale także jak najlepiej pokonać trudności w procesie przyswajania języka.

\section{ALTERNACJE MORFONOLOGICZNE W KONIUGACJI}

W polskiej glottodydaktyce (a także w nauczaniu innych języków słowiańskich) przyjęło się przypisywanie czasowników do poszczególnych grup koniugacyjnych. Podręczniki podpowiedzą nam, że np. brać należy do koniugacji $-e,-e s z$, widzieć do koniugacji -ę, -isz, natomiast jeść do grupy $-m,-s z$ (tudzież -em, -esz). Inna jest tradycja w nauczaniu języków germańskich; osoby uczące się niemieckiego powinny opanować formy około dwustu czasowników nieregularnych, podobnie jest w angielskim; służą temu specjalne listy, por. odpowiedniki czasowników brać, widzieć, jeść.

Tabela 1. Czasowniki nieregularne, przykłady niemieckie i angielskie

\begin{tabular}{|c|c|c|c|c|c|c|c|}
\hline \multirow{2}{*}{ Znaczenie } & \multicolumn{4}{|c|}{ Niemiecki } & \multicolumn{3}{c|}{ Angielski } \\
\cline { 2 - 8 } & Infinitiv & $\begin{array}{c}\text { Präsens } \\
\text { 3. Pers. } \\
\text { sg. }\end{array}$ & $\begin{array}{c}\text { Prät. } \\
\text { 3. Pers. } \\
\text { sg. }\end{array}$ & Part. Perf. & Infinitive & $\begin{array}{c}\text { Past } \\
\text { simple }\end{array}$ & Past part. \\
\hline 'brać' & nehmen & nimmst & $n a h m$ & genommen & take & took & taken \\
\hline 'widzieć' & sehen & siehst & sah & gesehen & see & saw & seen \\
\hline 'jeść' & essen & isst & $a \beta$ & gegessen & eat & ate & eaten \\
\hline
\end{tabular}

Źródło: opracowanie własne

Podsumowując: w polskiej tradycji glottodydaktycznej demonstruje się cały paradygmat odmiany, a w językach germańskich - głównie to, czego rzeczywiście trzeba się nauczyć na pamięć. Zakładając, że zadaniem glottodydaktyki jest między innymi pokazywanie, w jaki sposób opanować dany temat, w dalszej części tego artykułu demonstrujemy, iż pamięciowe opanowanie pierwszej i drugiej osoby czasu teraźniejszego oraz czasu przyszłego dokonanego czasowników polskich da więcej niż mechaniczne przypisywanie ich do grup koniugacyjnych. 
Już ponad sto lat temu, w obszernym podręczniku do nauki polskiego Polnische Konversations-Grammatik, Wladislaus Wicherkiewicz podkreślał, iż czasowniki polskie w czasie teraźniejszym oraz przyszłym dokonanym mają stabilne zakończenia, por. tabela 2.

Tabela 2. Zakończenia czasowników

\begin{tabular}{|c|c|c|}
\hline & Pers. Sing. & Pers. Plur. \\
\hline 1. & $-m$ oder $-e$ & $-m y$ \\
\hline 2. & $-s z$ & $-c i e$ \\
\hline 3. & - & $-a$ \\
\hline
\end{tabular}

Źródło: na podstawie Wicherkiewicz 1911, s. 127
Tabela 3. Koniugacja $-m,-s z$

\begin{tabular}{|c|c|c|}
\hline $\begin{array}{c}\text { jem, } \\
\text { powiem... }\end{array}$ & 1. poj. & $1 . \mathrm{mn}$. \\
\hline 1. & $-\boldsymbol{m}$ & $-m y$ \\
\hline 2. & $-s z$ & $-c i e$ \\
\hline 3. & - & $-j a /-d z q$ \\
\hline
\end{tabular}

Źródło: opracowanie własne

Wicherkiewicz pokazuje, iż tylko dobór końcówki osobowej -m lub -e w pierwszej osobie liczby pojedynczej jest problematyczny; pozostałe końcówki są przewidywalne. Oczywiście poloniści zauważą tu uproszczenia: zamiast końcówek osobowych $\mathrm{w}$ tabeli podane są zakończenia czasowników. Z dydaktycznego punktu widzenia jest to całkiem sensowne rozwiązanie. Wicherkiewicz komentuje pod tabelą, iż w polszczyźnie trudny jest nie tyle dobór końcówek, co znalezienie formy, do której daną końcówkę osobową należy dołączyć, a powodują to liczne alternacje $\mathrm{w}$ tematach fleksyjnych. Niestety prawie wszystkie podręczniki do nauki języka polskiego wprowadzają podział na trzy lub cztery koniugacje, zapożyczony z gramatyki historycznej tudzież opisowej, który $\mathrm{w}$ glottodydaktyce jest mało przydatny. W grupie zakończonej w pierwszej osobie na $-m$ (por. tabela 3 ) trzecia osoba liczby mnogiej prawie zawsze kończy się na -ją, por. ja mam, oni mają. W tej grupie tylko kilka czasowników odmienia się nieregularnie (są to jednak czasowniki o dużej frekwencji); różnice występują jedynie w ostatniej osobie liczby mnogiej, np. ja jem : oni jedza, a nie oni *jeja; ja wiem : oni wiedza, a nie: oni *wieja (gwiazdką zaznaczamy formy niepoprawne lub nieużywane). To rozszerzenie $-d z$ - obejmuje też formy pochodne, por. czas przyszły: ja zjem : oni zjedza; ja powiem : oni powiedza.

Samo przypisanie czasownika do którejś z grup koniugacyjnych nie wystarczy, aby go prawidłowo odmieniać. Spróbujmy popatrzeć na to z perspektywy studenta: jeśli dowie się, że czasownik brać należy do grupy -ę, -esz, to i tak nie jest on w stanie utworzyć pierwszej osoby na podstawie bezokolicznika (formy słownikowej), no bo jak, bra/ć : *braę? Jeśli opanuje pierwszą osobę, brać : ja biorę, to konsekwentnie powinno być dalej ja biorę : ty *bioresz. Oprócz pierwszej osoby trzeba więc pamięciowo opanować i drugą; sam wybór odpowiedniej koniugacji tu nie pomoże. Warto wiedzieć, iż czasowniki z grupy -ę, -ysz w ogóle nie podlegają alternacjom (o czym podręczniki do nauki polskiego jako obcego w zasadzie nie wspominają). Niewiele natomiast da informacja, że prosić należy 
do koniugacji -ę, -isz. Spróbujmy być konsekwentni - po odrzuceniu końcówki bezokolicznika (zamiast prawidłowych form ja prosze, ty prosisz) powinno być: prosi/ć : ja *prosię, ty prosisz. Jak widać, także w przypadku tego czasownika należy nauczyć się na pamięć i pierwszej, i drugiej osoby liczby pojedynczej, aby prawidłowo posługiwać się polszczyzną.

Interesujące są paralele polsko-niemieckie w tworzeniu form czasu teraźniejszego. Zacznijmy od typowych wzorów odmiany dla czasowników niemieckich. Czasownik nehmen 'brać' oraz sehen 'widzieć' należą do tzw. czasowników mocnych (nieregularnych). Czasownika zählen 'liczyć' nie znajdziemy w tabeli niemieckich czasowników mocnych (nieregularnych), gdyż odmienia się on regularnie - ale to też trzeba wiedzieć.

Porównajmy sposoby odmiany wybranych czasowników niemieckich i polskich $^{1}$.

Tabela 4. Formy czasu teraźniejszego wybranych czasowników polskich i niemieckich

\begin{tabular}{|c|c|c|c|c|c|}
\hline $\begin{array}{c}\text { brać } \\
(-\mathrm{e}, \text {-esz })\end{array}$ & $\begin{array}{c}\text { widzieć } \\
(-e ̨,- \text {-isz })\end{array}$ & $\begin{array}{c}\text { liczyć } \\
(-e ̨,-\mathrm{ysz})\end{array}$ & nehmen & sehen & zählen \\
\hline biore & widzę & liczę & ich nehme & ich sehe & ich zähle \\
\hline bierzesz & widzisz & liczysz & du nimmst & du siehst & du zählst \\
\hline bierze & widzi & liczy & er nimmt & er sieht & er zählt \\
\hline bierzemy & widzimy & liczymy & wir nehmen & wir sehen & wir zählen \\
\hline bierzecie & widzicie & liczycie & ihr nehmt & ihr seht & ihr zählt \\
\hline biora & widzq & liczq & sie nehmen & sie sehen & sie zählen \\
\hline
\end{tabular}

Źródło: opracowanie własne

Reasumując, zarówno w polskim, jak i w niemieckim trzeba się nauczyć na pamięć bezokolicznika oraz pierwszej i drugiej osoby liczby pojedynczej czasu teraźniejszego. Pozostałe formy są przewidywalne. W bardzo dużym skrócie budowę czasu teraźniejszego można opisać następująco: w obu językach alternacje występują w środkowej części paradygmatu odmiany. W niemieckim al-

\footnotetext{
${ }^{1}$ Cykl podręczników Odkrywamy język polski. Gramatyka dla uczacych (się) języka polskiego jako obcego, opublikowanych w języku polskim, niemieckim, angielskim i rosyjskim (odpowiednio: Madelska, Warchol-Schlottmann 2008; Madelska 2007, 2008; Madelska, Schwartz 2010; Madelska 2012) kontynuuje tradycję słowiańską (podział na koniugacje), ale zawiera także tabele prezentujące pierwszą i drugą osobę 1. poj. oraz trzecią osobą 1. mn. czasowników w czasie teraźniejszym i przyszłym dokonanym, zostawiając wybór metody nauczycielom i studentom. Wielotomowa, polsko-niemiecka gramatyka kontrastywna (Engel 2000, s. 557-568) nie ukazuje analogii w budowie form koniugacyjnych w obu językach, co jest spowodowane przyjęciem różnych sposobów opisu fleksji werbalnej dla każdego z nich. Analogie we fleksji werbalnej między polskim, niemieckim, angielskim i innymi językami podkreśla natomiast Perlin, ukazując jednocześnie, jak różne założenia teoretyczne wpływają na opisy języków (Perlin 2013, s. 203-213).
} 
ternacje znajdziemy w liczbie pojedynczej, w drugiej i trzeciej osobie. W języku polskim w czasownikach zakończonych w pierwszej osobie na -ę tylko pierwsza osoba liczby pojedynczej i ostatnia osoba liczby mnogiej mają formy bez alternacji. Można to porównać ze schematem bałwanka: głowa i noga (podstawa) mają formy bez alternacji, a alternacje znajdziemy w brzuchu bałwanka ${ }^{2}$. Jak wspomniano, w czasownikach na $-m$ wyjątkowe alternacje mogą pojawić się tylko na końcu paradygmatu odmiany, powiedzmy $-w$ dużm bucie klauna.

Warto zapamiętać, że czasowniki na -ować odmieniają się tak, jak studiować, a więc nie ja *studiowam, lecz ja studiuję, ty studiujesz. Schematyczny indeks a tergo (Tokarski 1993) notuje około 6.350 czasowników na -ować; obok czasowników rodzimych, jak świętować, według tego wzoru odmieniają się wszystkie internacjonalizmy, a więc zarówno lajkować, jak surfować i wiele, wiele innych. Taka informacja więcej daje studentowi niż przypisanie konkretnego czasownika do koniugacji -e, -esz.

Poniższa tabela ilustruje, że wprowadzając czas przyszły dokonany można odwołać się do schematów, funkcjonujących w odmianie czasu teraźniejszego: w czasownikach zakończonych w pierwszej osobie na - $e$ uczymy się form pierwszej i drugiej osoby, pozostałe formy są całkowicie przewidywalne. W czasownikach zakończonych na $-\boldsymbol{m}$ prawie wszystkie czasowniki odmieniają się regularnie, należy zapamiętać tylko kilka wyjątków, jak zjem : zjedza, powiem : powiedza, dam : dadzą.

Tabela 5. Czas przyszty dokonany

\begin{tabular}{|c|c|c|c|c|}
\hline $\begin{array}{c}\text { policzyć } \\
\text { grupie -ę, -ysz, } \\
\text { alternacje nie } \\
\text { występują }\end{array}$ & $\begin{array}{c}\text { zabrać } \\
(-\mathrm{e},-\mathrm{esz})\end{array}$ & $\begin{array}{c}\text { zjeść } \\
\text { wrócić } \\
\text { pierwsza osoba }- \text {-isz })\end{array}$ & $\begin{array}{c}\text { to -m; nieliczne } \\
\text { alternacje } \\
\text { są możliwe } \\
\text { tylko na końcu } \\
\text { paradygmatu }\end{array}$ & $\begin{array}{c}\text { zapytać } \\
(-\mathrm{m},-\mathrm{sz})\end{array}$ \\
\hline policzę & zabiorę & wrócę & zjem & zapytam \\
\hline policzysz & zabierzesz & wrócisz & zjesz & zapytasz \\
\hline policzy & zabierze & wróci & zje & zapyta \\
\hline policzymy & zabierzemy & wrócimy & zjemy & zapytamy \\
\hline policzycie & zabierzecie & wrócicie & zjecie & zapytacie \\
\hline policzq & zabiora & wrócq & zjedzą & zapytaja \\
\hline
\end{tabular}

Źródło: opracowanie własne

${ }^{2}$ Jeden $\mathrm{z}$ moich studentów, ucieszony, iż w mig zrozumiał polski system, skomentował tę regułę następująco: Aha, der polnische Schneemann hat einen größeren Bauch! 'Aha, polski batwanek ma większy brzuch!'. 
Jeśli wprowadzimy schematy batwanka i klauna na początku nauki, omawiając czas teraźniejszy, to te same schematy można później przywoływać, prezentując dalsze kategorie, jak czas przyszły dokonany, tryb rozkazujący czy imiesłowy. I tak podstawą do tworzenia trybu rozkazującego w czasownikach na - $\boldsymbol{e}$ są formy z alternacją (te z brzucha batwanka), oczywiście po odrzuceniu końcówek osobowych; w czasownikach na - $m$ tryb rozkazujący znajdziemy na końcu paradygmatu odmiany (w bucie klauna) po odrzuceniu -a, por.: No zjedz obiad, zabierz wino dla babci, zapytaj ja o zdrowie i wróć przed kolacja, tylko nie licz na moja pomoc! Unikanie skomplikowanych opisów zjawisk gramatycznych oraz dostosowanie metajęzyka do potrzeb i możliwości uczniów jest bardzo ważne, szczególnie na początkowym etapie nauki języka (por. Grochala 2016, s. 73-82). Pomagają też odpowiednio zaprezentowane przykłady, tabele czy rysunki, a przede wszystkim - ćwiczenia, zachęcające do samodzielnej pracy.

\section{ALTERNACJE MORFONOLOGICZNE W DEKLINACJI}

Systematyczną naukę alternacji w odmianie rzeczowników warto rozpocząć od rzeczowników w rodzaju żeńskim, w miejscowniku, w liczbie pojedynczej - tu widać najlepiej, iż wymiany w temacie fleksyjnym są regularne i przy niewielkim wysiłku już początkujący studenci są w stanie szybko je opanować. Formy miejscownika są potrzebne przy odpowiedziach na takie pytania, jak: o kim myślisz?, gdzie mieszkasz? i wielu innych. W poniższej tabeli zebrane są nazwy istot w rodzaju żeńskim w miejscowniku, ale oczywiście te same formy znajdziemy też w celowniku. Można zaproponować studentom, aby (po krótkiej instrukcji ze strony nauczyciela) odgadli, jak ma na imię osoba, o której się mówi. Jakie regularności da się tu zauważyć? ${ }^{3}$

${ }^{3}$ Trzeba dodać kilka uwag, np.: mówię o Filipie, o Józefie itp. można zrekonstruować i jako formy żeńskie (Filipa, Józefa) i jako męskie (Filip, Józef); nie odmieniamy żeńskich imion obcojęzycznych, zakończonych na spółgłoskę (a więc mówię o Ruth, o Carmen); polskie imiona podlegają licznym zdrobnieniom, przy czym przyrostki deminutywne dodajemy często tylko do początkowej części imienia, por. Barbara : Basia, Basiunia, Basieńka itd. Takie zdrobniałe formy imion też podlegają odmianie przez przypadki. 
Tabela 6. Imiona i określenia żeńskie w mianowniku liczby pojedynczej

\begin{tabular}{|c|c|c|c|c|c|c|c|c|c|}
\hline \multicolumn{10}{|c|}{ O kim mówisz? Mówię o... } \\
\hline & I & & II & & III & & IV & & $\mathbf{V}$ \\
\hline Filipie & $\mathbf{p}$ & Renacie & $\mathbf{t}$ & babci & ć & złośnicy & $\begin{array}{c}\mathbf{c} \\
(\mathrm{cz})\end{array}$ & Ance & $\mathbf{k}$ \\
\hline babie & b & Idzie & d & Jadzi & dź & $\begin{array}{l}\text { jędzy } \\
\text { Żaży }\end{array}$ & $\begin{array}{c}d z \\
\text { (d) } \dot{\mathbf{z}}\end{array}$ & Kindze & $\mathbf{g}$ \\
\hline Józefie & f & Larysie & $\mathbf{s}$ & Kasi & ś & Nataszy & $\mathbf{s z}$ & macosze & ch \\
\hline Sławie & $\mathbf{w}$ & Izie & $\mathbf{z}$ & Rózi & $\mathbf{z}$ & Róży & $\dot{\mathbf{z}}$ & & \\
\hline \multirow[t]{4}{*}{ Romie } & m & Annie & $\mathbf{n}$ & Ani & ń & & & & \\
\hline & & Larze & $\mathbf{r}$ & & & Zorzy & $\mathbf{r z}$ & & \\
\hline & & Ludmile & 1 & Lili & 1 & & & & \\
\hline & & & & $\begin{array}{c}\text { Alicji, } \\
\text { Mai }\end{array}$ & $\mathbf{j}$ & & & & \\
\hline
\end{tabular}

Źródło: opracowanie własne

Zajęcia, na których obcokrajowcy dowiadują się, jak można spolszczyć imiona ich samych oraz znanych im osób mogą być bardzo zabawne - to dobra rozgrzewka do porządkowania polskich alternacji. Łatwa jest rekonstrukcja imion z grupy czwartej ( $-y$ zamieniamy na $-a$ ); oraz trzeciej (dodajemy $-a$; jedynie sonorne zakończenie tematu fleksyjnego wymaga uwzględnienia reguł ortograficznych, jak Maja: Mai). Tu widać wyraźnie, że rzeczowniki miękkotematowe nie podlegają alternacjom. W grupie pierwszej spółgłoski zmiękczone (wargowe) $\left[\mathrm{p}^{\mathrm{j}}, \mathrm{b}^{\mathrm{j}}, \mathrm{m}^{\mathrm{j}}, \mathrm{f}, \mathrm{w}^{\mathrm{j}}\right]$ trzeba wymienić na ich twarde odpowiedniki; w ortografii wystarczy zmienić -ie na - $a$. Najciekawsza jest dla nas grupa druga (spółgłoski przedniojęzykowe) i piąta (spółgłoski tylnojęzykowe), gdyż tu alternacje są bardziej wyraziste: aby zrekonstruować mianownik, przykładom z grupy drugiej i piątej trzeba przywrócić twardy temat fleksyjny, co ilustruje powyższa tabela. Tworzenie form miejscownika w liczbie pojedynczej omawiamy tu bardzo skrótowo; podobne przedstawienie tego tematu można znaleźć w cytowanym już cyklu podręczników Odkrywamy język polski (przypis 1). Należy tu jedynie dodać, że w deklinacji spółgłoski spalatalizowane (inaczej - zmiękczone $\left[\mathrm{p}^{\mathrm{j}}, \mathrm{b}^{\mathrm{j}}, \mathrm{r}^{\mathrm{j}}\right]$ itd., w ortografii oznaczane przez połączenie z $i$ lub $j$ ) podlegają takim samym procesom jak palatalne (miękkie, środkowojęzykowe), a więc: to jest Katja, Lamia, Daria : mówię o Katji, Lamii, Darii. Aby nie komplikować rozważań, analogiczne przykłady nie będą szczegółowo omawiane, a z zapisu fonetycznego wykorzystujemy jedynie jotę dla oznaczenia głosek zmiękczonych, por. $\left[\mathrm{p}^{\mathrm{j}}, \mathrm{b}^{\mathrm{j}}, \mathrm{m}^{\mathrm{j}}, \mathrm{f}, \mathrm{w}^{\mathrm{j}}\right]$. 
Bogaty zestaw ćwiczeń z fleksji imiennej zawiera Przygoda z gramatyka..., w którym znajdziemy też tabele, zestawiające procesy morfonologiczne $\mathrm{w}$ deklinacji.

Tabela 7. Wymiany spółgłosek w odmianie przymiotników i rzeczowników w liczbie pojedynczej

\begin{tabular}{|c|c|c|c|c|c|c|c|c|c|c|c|c|c|c|c|}
\hline $\begin{array}{c}\text { Spółgłoski } \\
\text { consonants }\end{array}$ & \multicolumn{10}{|c|}{ Wymiany spółgłosek - Alternations of consonants } \\
\hline $\begin{array}{c}\text { twarde } \\
\text { (hard) }\end{array}$ & $\mathrm{p}$ & $\mathrm{b}$ & $\mathrm{f}$ & $\mathrm{w}$ & $\mathrm{t}$ & $\mathrm{d}$ & $\mathrm{s}$ & $\mathrm{z}$ & $\mathrm{k}$ & $\mathrm{g}$ & $\mathrm{ch}$ & $\mathrm{m}$ & $\mathrm{n}$ & $\mathrm{r}$ & $\mathrm{t}$ \\
\hline $\begin{array}{c}\text { miękkie } \\
\text { (soft) }\end{array}$ & $\mathrm{pi}$ & $\mathrm{bi}$ & $\mathrm{fi}$ & $\mathrm{wi}$ & $\begin{array}{c}\mathrm{c} \\
\mathrm{ci}\end{array}$ & $\begin{array}{c}\mathrm{dz} \\
\mathrm{dzi}\end{array}$ & $\begin{array}{c}\text { s } \\
\mathrm{si}\end{array}$ & $\begin{array}{c}\mathrm{z} \\
\mathrm{zi}\end{array}$ & $\mathrm{ki}$ & $\mathrm{gi}$ & $\begin{array}{c}\mathrm{s} \\
\mathrm{si}\end{array}$ & $\mathrm{mi}$ & $\begin{array}{c}\mathrm{n} \\
\mathrm{ni}\end{array}$ & & $\mathrm{li}$ \\
\hline $\begin{array}{c}\text { funkcjonalne } \\
\text { miękkie } \\
\text { (hardened) }\end{array}$ & & & & & $\mathrm{c}$ & $\mathrm{dz}$ & $\mathrm{sz}$ & $\dot{\mathrm{z}}$ & $\begin{array}{c}\mathrm{c} \\
\mathrm{cz}\end{array}$ & $\begin{array}{c}\mathrm{z} \\
\mathrm{dz}\end{array}$ & $\mathrm{sz}$ & & & $\mathrm{rz}$ & 1 \\
\hline
\end{tabular}

Źródło: Pyzik 2000, s. 412

Winę za to, że polski uchodzi za język trudny, przypisuje się często wymowie, co nie znajduje pokrycia w rzeczywistości (por. Madelska 2009 i Madelska 2010). Obecny stan badań pozwala stwierdzić, iż przeciętny język ma około dziewięciu samogłosek i dwudziestu trzech spółgłosek; liczba samogłosek w systemach fonologicznych waha się jednak od trzech do czterdziestu sześciu, a liczba spółgłosek - od jedenastu do ponad stu. Porównajmy polszczyznę z takimi językami jak niemiecki, angielski czy francuski: we wszystkich tych językach mamy podobną liczbę spółgłosek (poniżej trzydziestu), natomiast polski system wokaliczny, ze swoimi sześcioma samogłoskami ustnymi i dwiema nosówkami $e$, $q$ (tudzież, w zależności od przyjętej teorii, z nosowymi [j̃ , w̃], por. Madelska 2005) jest prostszy niż systemy wokaliczne w języku niemieckim, angielskim czy francuskim. Za fonologicznie bliski językowi polskiemu uchodzi język hiszpański, tego z kolei nie zalicza się do języków o trudnej wymowie, tak więc mit o ,trudnej” polszczyźnie musi mieć swoje korzenie gdzie indziej.

Problemem w polszczyźnie nie jest liczba fonemów, natomiast fascynować mogą nasze alternacje morfonologiczne. Obcokrajowców nieprzyzwyczajonych do tego, że imiona mogą podlegać odmianie, dziwi i bawi sposób, w jaki zwracają się do nich Polacy, por. Mamy w grupie Maksa, Davida, Sarę i Ingę, mówimy więc o Maksie, Davidzie, Sarze i Indze. Alternacje w polskiej fleksji są w dużym stopniu przewidywalne i regularne, ale trzeba się ich systematycznie uczyć. Analogie między alternacjami morfonologicznymi w koniugacji i w deklinacji są nieczęsto omawiane w podręcznikach do nauki języka polskiego jako obcego, a w artykułach z dziedziny glottodydaktyki czy nawet w pracach naukowych znajduje się niestety wiele niedopowiedzeń i nieścisłości. Systematyczne wprowadzanie 
tematu alternacji od początku nauki języka polskiego ułatwia rozumienie, samodzielną analizę i tworzenie tekstów, a przede wszystkim porządkuje podstawy gramatyczne i nie pozostawia ucznia samego wobec ogromu (tylko z pozoru przypadkowych) form wyrazowych.

Poza składnią liczebników (por. mam dwóch braci, dwie siostry i dwoje dzieci) za trudną w polszczyźnie uchodzi składnia rzeczowników męskoosobowych. Odstraszać mogą takie zmiany form wyrazowych, jakie występują w przykładzie te stare piloty leżały pod mostem, ale: ci starzy piloci leżeli na moście. Spróbujmy porównać alternacje polskie i niemieckie:

Tabela 8. Przykłady alternacji w języku polskim i niemieckim

$\begin{array}{cccc}\text { Mój brat } & \text { bierze } & \text { odkucharza } & \text { kwaszone ogórki. } \\ \text { Moi bracia } & \text { biorq } & \text { odkucharki } & \text { cośkwaśnego. } \\ \text { Mein Bruder } & \text { nimmt } & \text { von dem Koch } & \text { saure Gurken. } \\ \text { Meine Brüder } & \text { nehmen } & \text { von der K̈̈chin } & \text { was Säuerliches. } \\ & \text { Źródło: opracowanie własne } & \end{array}$

W polszczyźnie zdecydowana większość alternacji obejmuje spółgłoski; te wymiany są w dużym stopniu przewidywalne. Alternacje samogłoskowe są o wiele rzadsze, lecz często nieprzewidywalne - trzeba się ich po prostu nauczyć na pamięć. W niemieckim zdecydowanie przeważają wymiany samogłoskowe (tzw. umlaut $a: \ddot{a}, u: \ddot{u}, o: \ddot{o}$, au : äu), reguł jest tu niewiele, za to wyjątków - cała masa. Pod tym względem niemiecki jest o wiele bardziej wymagający niż polski.

Budowa liczby mnogiej rzeczowników określających grupy mężczyzn to jeden $\mathrm{z}$ trudniejszych tematów w polskiej deklinacji. Przede wszystkim trzeba tu wyróżnić grupę rzeczowników na -owie; to zakończenie honoruje wysokie urzędy czy ważnych członków rodziny, ale pomaga też tworzyć liczbę mnogą od jednosylabowych nazw narodowości, por. sędziowie, synowie, Belgowie. Dublety typu profesorowie : profesorzy zdradzają, iż polszczyzna dopuszcza różne sposoby tworzenia liczby mnogiej. Poza powyższymi przykładami w wielu rzeczownikach męskoosobowych tworzenie liczby mnogiej wymaga nie tylko doboru odpowiedniej końcówki, lecz także uwzględnienia alternacji w tematach fleksyjnych. Dodatkowo, budując zdania z homonimami, które należą albo do kategorii męskoosobowości (mężczyźni lub grupy mieszane), albo do żeńsko-rzeczowości, por. piloty : piloci, do opisywanych rzeczowników trzeba też dopasować deklinabilia. Mając na myśli klucze nastawne, powiemy: To były te duże francuzy, które leżały w szopie. Jeśli natomiast mówimy o ludziach, do rzeczownika trzeba dopasować wszystkie odmienne części mowy, które się do niego odnoszą: To byli ci duzi Francuzi, którzy leżeli w szopie. Dzięki temu, że te alternacje są w zdecy- 
dowanej większości przewidywalne, przy odpowiednim przygotowaniu student może nie tylko rekonstruować, ale też samodzielnie tworzyć formy liczby mnogiej nowo poznanych słów.

Nazywanie mężczyzn określeniami bez alternacji bywa funkcjonalne - może mieć na celu wyrażenie lekceważenia, ironii czy pogardy, por. ci młodzi biznesme$n i$ : te młode biznesmeny. Brak alternacji może też pociągać za sobą modyfikację znaczenia: Gdzie ci ciężko pracujący chtopi 'rolnicy'? / Gdzie te silne, młode chtopy 'faceci'? W wielu leksemach z natury pejoratywnych przeważają formy bez alternacji, usłyszymy więc raczej: te głupie leniuchy, cymbaty, jełopy, tępaki, psie syny, a nie: ci ghupi leniusi, cymbali, jetopi, tepacy, psi synowie.

$\mathrm{W}$ języku polskim odziedziczonym lub w polszczyźnie naszych wschodnich sąsiadów często spotyka się problemy ze stosowaniem poprawnych form wyrazowych w odniesieniu do kategorii męskoosobowości. Bardzo trudno wykorzenić takie tendencje, a może to pociągać za sobą problemy w komunikacji. Jeśli początkujący student, mówiący z wyraźnym obcym akcentem, będzie opowiadał, że w jego akademiku mieszkają Francuzy i Polaki, natywni użytkownicy polskiego potraktują to jako słabą kompetencję językową, a nie celowe lekceważenie współmieszkańców. Osoby mówiące prawie bez akcentu, na przykład te, dla których polski jest językiem odziedziczonym, powinny unikać tego typu błędów, gdyż mogą być one interpretowane przez słuchaczy nie jako pomyłki, lecz jako przejawy arogancji czy niepoprawności politycznej ${ }^{4}$.

Młodym nauczycielom oraz studentom dość dobrze znającym język polski proponujemy zabawę, polega ona na „nadaniu męskoosobowości” rzeczownikom, wyróżnionym thustym drukiem w opowiadaniu Stare piloty ${ }^{5}$. Wykorzystano w nim rzeczowniki mające co najmniej dwa znaczenia, jedno żeńsko-rzeczowe, a drugie męskoosobowe. Sama zamiana tekstu na wersję męskoosobową nie powinna sprawić trudności osobom polskojęzycznym; ciekawsze jest pytanie o to, jakie reguły trzeba zastosować, aby zmienić rodzaj żeńsko-rzeczowy na rodzaj męskoosobowy. W których częściach mowy należy się spodziewać alternacji morfonologicznych? Jak ułatwiać obcokrajowcom opanowanie tych procesów? W dalszej części artykułu pokazujemy, iż nie jest to trudny temat, warunkiem sukcesu dydaktycznego są jednak wiedza i umiejętności nauczycieli. Alternacjami warto się zajmować od początkowych etapów nauki, gdyż podobne schematy alternacyjne obejmują prawie wszystkie, liczne i z pozoru skomplikowane,

${ }^{4} \mathrm{~W}$ polskiej literaturze nie brakuje gier z kategorią męskoosobowości; ciekawe przykłady znajdziemy w Kulcie (Orbitowski 2019): Kardynaty i biskupy nas znienawidzity, s. 132; Brud i smród naniosty na klatke te wstrętne wernychory, s. 179, Chlopy pracowaty tam wielkie, pótnagie i połapałem się, że nie znam żadnego z tych facetów, s. 314.

${ }^{5}$ Celem ćwiczenia jest między innymi wzmacnianie świadomości glottodydaktycznej młodych nauczycieli języka polskiego jako obcego; o potrzebie takich działań piszą m.in. Karasek i Gaze (2019, s. 139-148). Nowsze prace wyróżniają trzy rodzaje męskie: męskoosobowy, męskożywotny, męskonieżywotny (por. Pałuszyńska 2019). 
wymiany spółgłoskowe w polszczyźnie; dotyczy to i koniugacji, i deklinacji, i stopniowania, a w dużym zakresie także słowotwórstwa.

Zamieszczone poniżej opowiadanie Stare piloty zostało spreparowane dla celów dydaktycznych. Homonimy oraz ich określenia dobrano tak, aby uzyskać możliwie różnorodne zakończenia tematów fleksyjnych (nieocenione pomoce w szukaniu przykładów to indeksy a tergo, por. Tokarski 1993; Bańko, Komosińska, Stankiewicz 2003). Niektóre zdania brzmią mało realistycznie, ale można sobie wyobrazić zabawę przebierańców - wystarczy trochę wyobraźni. A potem trzeba tylko sprawdzić, co się dzieje w całej wypowiedzi, jeśli przywrócimy ludzką postać rzeczownikom, wyróżnionym wytłuszczonym drukiem. Tekst z odpowiednio dopasowanymi formami fleksyjnymi podany jest poniżej, w drugiej wersji opowiadania, zatytułowanej Starzy piloci.

W wersji męskoosobowej opowiadania Starzy piloci mowa jest nie o zwierzętach czy przedmiotach, lecz o mężczyznach tudzież o grupach mieszanych. Tłustym drukiem wyróżniono wyrazy, których formy fleksyjne trzeba dopasować do danej kategorii, jeśli zmieni się znaczenie rzeczowników.

Stare piloty. Formy żeńsko-rzeczowe

Podczas karnawatu siedziałam sobie z koleżankami w milym lokalu na Starówce. Wybrałyśmy stolik na chodniku, aby ogladać przechodzacych obok przebierańców. Jako pierwsze minęty nas wysokie akademiki, a za nimi sunęty tycie prymusy. Może planowano piknik? Dalej stali ludzie w niebieskich koszulkach z żóttymi krzyżami. Wszyscy mieli szerokie spodnie. Tamte szwedy byly dość grube, ale i tak eleganckie. Chyba byt tu zjazd etnograficzny, bo obok nas pojawity sie Kaszuby. Potem doszly Mazury, zapraszając nad piękne jeziora. $W$ innej grupie ktoś zachwycat się Starówka, a jego kolega dodat, częstując przechodniów jedzeniem w matych stoiczkach:

- Bohoniki i Kruszyniany też sa piękne... Oj, tak, u nas tė̇ pięknie! - To chyba byty polskie tatary.

W barwnej grupie przebrano się albo za warkocze, albo za narzędzia; ktoś krzyknąt wesoto:

- Ma chérie, arrête! - To chyba byly różne francuzy.

Na dlugiej lawce odsuwaty się od siebie tajemnicze, ciche pustelniki. Nie byly one ani aktywne, ani uprzejme. Między nimi leżaty duże piloty, raczej stare i mało nowoczesne. Pod pomnikiem Syrenki grzały się na stońcu tluste, gorace okularniki. Czy one nas widziały? Na rynku byty wielkie szachownice. Ludzie przesuwali się po polach szachowych jak pionki. Które hetmany będa szybsze: biate czy czarne? A które zostana zbite? Na Starówkę wtoczyly się klawisze, grajace piosenke „Czarny chleb i czarna kawa”. Po chodniku ścigaty się szybkie biegacze; miaty cienkie, ale dhugie i mocne nogi. Od biegania byty całkiem mokre. Na ulice nagle wjechały junaki. Ale za to jakie - widać, że zawsze niezawodne, zadbane i wypieszczone! Naprawde je podziwiałyśmy! Nieco z boku była mała galeria sztuki; grafiki informowały, jakie będa w niej wystawy. W drzwiach 
galerii tkwity małe judasze. Obok galerii stały duże, widoczne z daleka kolaże. Miło było na nie popatrzeć. Zza rogu wybiegły rude, złe boksery, wygladajace bardzo groźnie, ale kobiety odciagnęty je $w$ dwie różne strony.

Za nami siedziaty wesole rogacze; rozmawiaty o tym, z kim flirtuja ich partnerki i cieszyty się, że moga sobie odpoczać w spokoju od matżeńskich obowiązów.

- Czy tu jest bezpiecznie? - zapytałam szefa lokalu.

- Muszę przyznać, że tu bywało różnie - odpowiedziat - ale odkad pilnuja baru nasze nowe, tyse goryle, mamy tu spokój. Nie sa tanie, ale to mi zupetnie nie przeszkadza, że sa drogie; ważne, że nie sa tępe, ale dobre i skuteczne. Tylko skape jelenie oszczędzaja na pracownikach.

- A czy można o ludziach mówić goryle? - zdziwiłam się.

- No cóż, oni sami tak o sobie mówia - uśmiechnąt się szef. Polecał też wtoskie dania.

- Jeśli chodzi o kuchnię, to najlepsze sa Wtochy; maja oliwki, owoce, warzywa, w ogóle sa bardzo zdrowe.

Kiedy szłam do łazienki, w korytarzu zauważyłam malusie prusaki. Czemu te prusaki nie uciekty, nawet kiedy krzyknętam? Może one byty gtuche? Szef uprzedził nas, że na wieczór zaplanowano koncert na rzecz bezdomnych zwierzat. Młode albinosy miały próbę chóru. Śpiewały dość głośno, na szczęście szybko sobie poszly. Przed koncertem zaczęty strzelać fajerwerki. Bawiace się obok dzieci były pilnowane przez opiekunów. Nagle jakieś patrony przeleciaty koło nas, aż się przestraszytyśmy.

Chciatyśmy opublikować ten tekst $i$ dobrze wypaść przed wydawca, potrzebne więc nam byty profesjonalne, solidne korektory.

Starzy piloci. Formy męskoosobowe

Podczas karnawału siedziałam sobie z koleżankami w mitym lokalu na Starówce. Wybratyśmy stolik na ulicy, aby ogladać przechodzacych obok przebierańców. Jako pierwsi minęli nas wysocy akademicy, a za nimi sunęli tyci prymusi. Może planowano piknik? Dalej stali ludzie w niebieskich koszulkach z żóttymi krzyżami. Wszyscy mieli szerokie spodnie. Tamci Szwedzi byli dość grubi, ale i tak eleganccy. Chyba byt tu zjazd etnograficzny, bo obok nas pojawili się Kaszubi. Potem doszli Mazurzy, zapraszając nad piękne jeziora. W innej grupie ktoś zachwycat się Starówka, a jego kolega dodat, częstując przechodniów jedzeniem $w$ matych słoiczkach:

- Bohoniki i Kruszyniany też sa piękne... Oj, tak, u nas też pięknie - To chyba byli polscy Tatarzy.

W barwnej grupie przebrano się albo za warkocze, albo za narzędzia; ktoś krzyknąt wesoło:

- Ma chérie, arrête! - To chyba byli różni Francuzi.

Na długiej ławce odsuwali się od siebie tajemniczy, cisi pustelnicy. Nie byli oni ani aktywni, ani uprzejmi. Między nimi leżeli duzi piloci, raczej starzy i mało nowocześni. Pod pomnikiem Syrenki grzali się na słońcu tluści, goracy okularnicy. Czy oni nas widzieli? Na rynku byty wielkie szachownice. Ludzie 
przesuwali się po polach szachowych jak pionki. Którzy hetmani będa szybsi: biali czy czarni? A którzy zostana zbici? Na Starówkę wtoczyli się klawisze, grajacy piosenke ,, Czarny chleb i czarna kawa”. Po chodniku ścigali się szybcy biegacze; mieli cienkie, ale dtugie i mocne nogi. Od biegania byli catkiem mokrzy. Na ulice nagle wjechali junacy. Ale za to jacy - widać, że zawsze niezawodni, zadbani $i$ wypieszczeni. Naprawdę ich podziwiatyśmy! Nieco z boku była mała galeria sztuki; graficy informowali, jakie będa $w$ niej wystawy. $W$ drzwiach galerii tkwili mali Judasze. Obok galerii stali duzi, widoczni z daleka kolarze. Miło było na nich popatrzeć. Zza rogu wybiegli rudzi, źli bokserzy, wyglądający bardzo groźnie, ale kobiety odciągnęty ich $w$ dwie różne strony.

Za nami siedzieli weseli rogacze; rozmawiali o tym, z kim flirtuja ich partnerki i cieszyli się, że moga sobie odpoczać w spokoju od matzeńskich obowiązów.

- Czy tu jest bezpiecznie? - zapytałam szefa lokalu.

- Musze przyznać, że tu bywało różnie - odpowiedziat - ale odkąd pilnuja baru nasi nowi, bysi goryle, mamy tu spokój. Nie sa tani, ale to mi zupetnie nie przeszkadza, że sa drodzy. Ważne, że nie sa tepi, ale dobrzy i skuteczni. Tylko skapi jelenie oszczędzaja na pracownikach.

- A czy można o ludziach mówić goryle? - zdziwiłam się.

- No cóż, oni sami tak o sobie mówia - uśmiechnąt się szef. Polecat też włoskie dania.

- Jeśli chodzi o kuchnię, to najlepsi sa Wtosi; maja oliwki, owoce, warzywa, w ogóle sa bardzo zdrowi.

Kiedy szłam do łazienki, w korytarzu zauważyłam malusich Prusaków. Czemu ci Prusacy nie uciekli, nawet kiedy krzyknęłam? Może oni byli glusi? Szef uprzedzit nas, że na wieczór zaplanowano koncert na rzecz bezdomnych zwierząt. Młodzi albinosi mieli próbę chóru. Śpiewali dość głośno, na szczęście szybko sobie poszli. Przed koncertem zaczęty strzelać fajerwerki. Bawiace się obok dzieci były pilnowane przez opiekunów. Nagle jacyś patroni przelecieli koło nas, aż się przestraszytyśmy.

Chciatyśmy opublikować ten tekst i dobrze wypaść przed wydawca, potrzebni więc nam byli profesjonalni, solidni korektorzy.

Porównanie obu tekstów pokazuje, iż wszystkie deklinabilia wymagają szczególnych form odmiany, co widać w liczbie mnogiej i w mianowniku, i w bierniku. Studentom słabiej znającym polski, mającym problemy z ,nadaniem męskości" rzeczownikom wyróżnionym w pierwszym tekście, można polecić rozpoczęcie ćwiczeń od „odebrania (kategorii) męskości” bohaterom opowiadania Starzy piloci; zrekonstruowanie form żeńsko-rzeczowych na podstawie form męskoosobowych będzie na pewno łatwiejszym zadaniem.

Przykłady z opowiadań o pilotach prezentujemy w dwóch tabelach; pierwsza zawiera wybrane rzeczowniki w liczbie mnogiej, a druga - przymiotniki, imiesłowy, liczebniki i zaimki, określające odpowiednio grupy męskoosobowe i żeńsko-rzeczowe. Łatwo zauważyć, że w obu tabelach występują podobne procesy alternacyjne. 
Tabela 9. Alternacje w rzeczownikach męskoosobowych

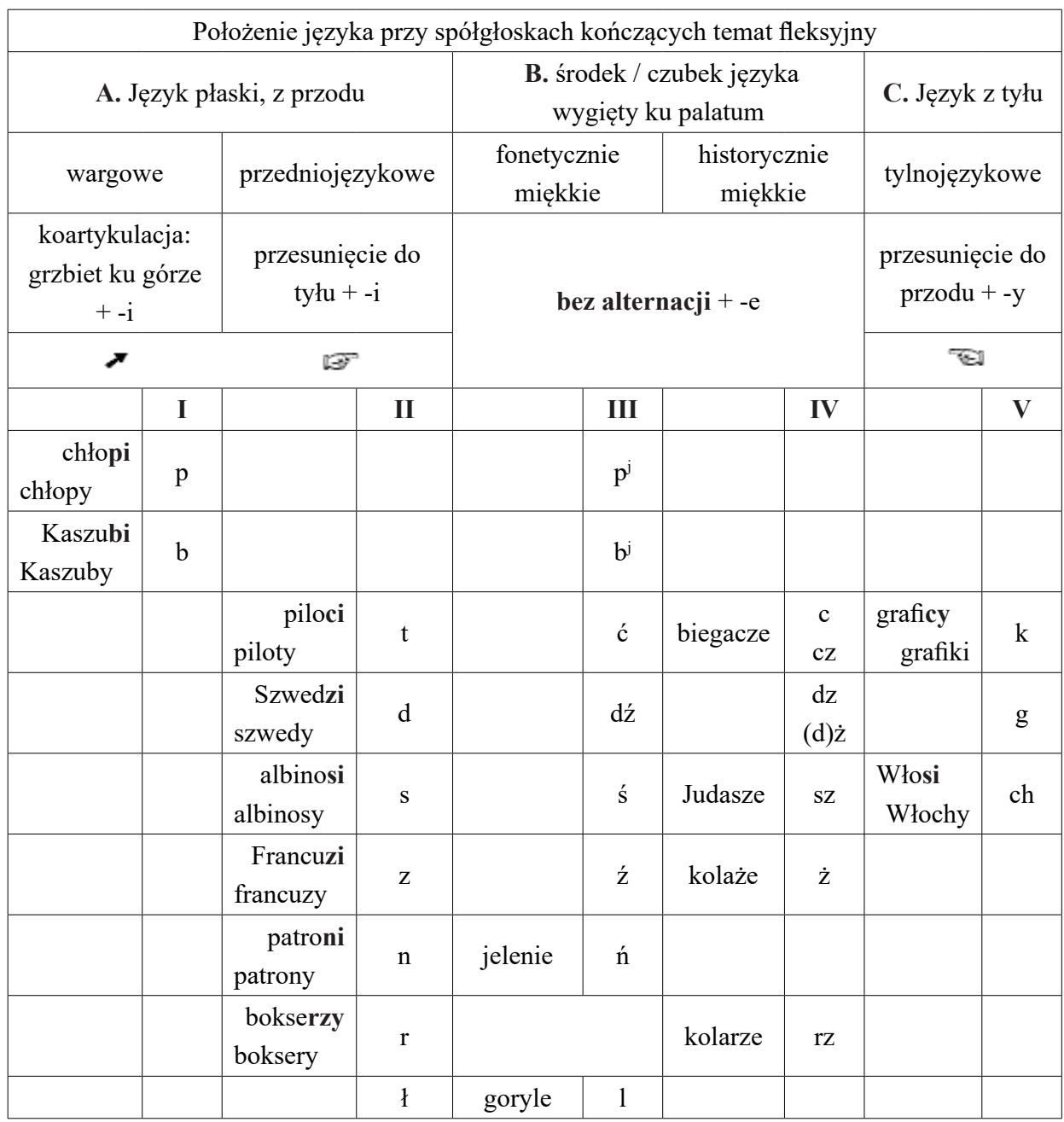

Źródło: opracowanie własne

W zależności od zakończenia tematu fleksyjnego możemy wydzielić trzy grupy spółgłosek: A. wymawiane z przodu, B. wymawiane na środku, C. wymawiane z tyłu jamy ustnej. Spółgłoski przednie trzeba cofnąć, tylne - przesunąć do przodu; te dwa ruchy języka charakteryzują typowe polskie alternacje. Podczas tych procesów język zbliża się ku palatum, a więc w polskiej fleksji mamy do czynienia ze szczególnym rodzajem oboczności - są to głównie palatalizacje. Tematy zakończone na spółgłoski fonetycznie i historycznie miękkie (palatalne i alweolarne), czyli te, które są artykułowane w okolicy palatum, nie podlegają alternacjom (mówiąc inaczej: nie da się ich już wyżej podnieść, bo nie przebijemy językiem podniebienia twardego). 
Opanowanie alternacji ułatwia znajomość podstaw fonetyki. Komentarze na temat fonetyki mogą być nudne w formie pisanej, natomiast na bezpośrednich zajęciach ze studentami klasyfikację głosek da się ciekawie omawiać, wykorzystując elementy zabawy.

Gdy mówimy o grupie mężczyzn, język powinien być blisko podniebienia twardego (palatum). Jeśli on już tam jest, jak w grupie B (czubek lub środek języka wygina się ku palatum), wystarczy dodać końcówkę -e; por. biegacz : biegacze to mogą być i 'mężczyźni', i 'żuki'.

W grupie A mamy spółgłoski wymawiane w przedniej części narządu mowy. W rzeczownikach żeńsko-rzeczowych do tematu fleksyjnego dodajemy końcówkę $-y$. W męskoosobowych pod wpływem końcówki -i przesuwamy język w kierunku podniebienia twardego, ku palatum (środkowa część tabel); ten ruch języka symbolizuje w tabelach palec wskazujący ${ }$. Przy głoskach wymawianych wargowo (pierwsza kolumna) w ortografii wystarczy tylko dodać -i (por. chłop : chłopi, ale też detektyw : detektywi, olbrzym : olbrzymi). Spółgłoskom wargowym towarzyszy przy tym wygięcie środka języka ku górze, ku palatum (koartykulacja). W grupie głosek artykułowanych przy pomocy przedniej części języka, jak - $t,-d,-s$, cofnięcie go pociąga za sobą większe zmiany (mówiąc obrazowo: druga kolumna przeskakuje do tyłu, na miejsce trzeciej), por. pilot : piloci, Szwed : Szwedzi, prymus : prymusi. W przypadku -r mamy systematyczną wymianę $r: r z$ (głębsze cofnięcie języka), por. bokser : bokserzy. W sumie wszystkie głoski przednie (wargowe i językowe) podlegają tym samym procesom morfonologicznym, można je więc przedstawić w jednej kolumnie.

Jeśli język jest z tyłu, jak w grupie $\mathbf{C}$ (w tabelach - po prawej stronie), przesuwamy go do przodu (piąta kolumna przechodzi na czwartą, co symbolizuje znak छ), stąd grafik: graficy, ale też biolog : biolodzy. W przypadku -ch alternacja jest głębsza (przesuwamy język o dwie pozycje, aż do -ś), por. Włoch : Włosi; Czech : Czesi.

Tabela alternacji w rzeczownikach prezentuje te same procesy, które łatwo zauważyć w innych deklinabiliach, por. podane poniżej przykłady przymiotników i imiesłowów, a także liczebników i zaimków, określających rzeczowniki w liczbie mnogiej.

Podsumowując: określenia rzeczowników żeńsko-rzeczowych (kobiet, małych istot, zwierząt, przedmiotów czy abstraktów) przyjmują końcówkę -e. Zajmują one w tabeli skrajne pozycje: język jest na peryferiach, albo w przedniej, albo w tylnej części narządów mowy. Jeśli natomiast mówimy o grupie z mężczyznami, deklinabilia podlegają centralizacji: przyjmują końcówkę $-i$, która wymusza regularne palatalizacje. Jedynie po $-c,-c z$ oraz $-r z$ występuje końcówka $-y$, co ma uzasadnienie w procesach historycznych (por. te tajemnicze, cicho rozmawiajace, chore kobiety / ci tajemniczy, cicho rozmawiajacy, chorzy mężczyźni). Wymiany samogłoskowe, jak w przykładzie wesołe : weseli, spotyka się rzadko, głównie w wyrazach rodzimych. 
Tabela 10. Przymiotniki, imiesłowy, liczebniki i zaimki określajace rzeczowniki w liczbie mnogiej

\begin{tabular}{|c|c|c|c|c|c|c|c|}
\hline \multicolumn{4}{|c|}{ kierunek zmian w temacie } & \multicolumn{4}{|c|}{ kierunek zmian w temacie } \\
\hline \multicolumn{2}{|c|}{$\begin{array}{c}\text { deklinabilia } \\
\text { żeńsko-rzeczowe }\end{array}$} & \multicolumn{3}{|c|}{ deklinabilia męskoosobowe i żeńsko-rzeczowe } & & \multicolumn{2}{|c|}{$\begin{array}{c}\text { deklinabilia } \\
\text { żeńsko-rzeczowe }\end{array}$} \\
\hline tępe & $\mathrm{p}$ & $\begin{array}{r}\text { tępi } \\
\text { głupie : głupi }\end{array}$ & $\mathrm{p}^{\mathrm{j}}$ & & & & \\
\hline słabe & $\mathrm{b}$ & słabi & $b^{j}$ & & & & \\
\hline & $\mathrm{f}$ & & $\mathrm{f}$ & & & & \\
\hline zdrowe & $\mathrm{w}$ & zdrowi & $\mathrm{w}^{\mathrm{j}}$ & & & & \\
\hline $\begin{array}{r}\text { uprzejme } \\
\text { same }\end{array}$ & $\mathrm{m}$ & $\begin{array}{r}\text { uprzejmi } \\
\text { sami }\end{array}$ & $\mathrm{m}^{\mathrm{j}}$ & & & & \\
\hline $\begin{array}{r}\text { tamte thuste } \\
\text { te szóste }\end{array}$ & $\mathrm{t}$ & $\begin{array}{r}\text { tamci tłuści } \\
\text { ci szóści } \\
\text { tycie : tyci } \\
\text { trzecie : trzeci }\end{array}$ & ć & $\begin{array}{r}\text { jacy wysocy } \\
\text { eleganccy } \\
\text { gorący : gorące } \\
\text { tajemniczy : tajemnicze }\end{array}$ & $\begin{array}{l}\mathrm{c} \\
\mathrm{cz}\end{array}$ & $\begin{array}{r}\text { jakie } \\
\text { wysokie } \\
\text { eleganckie }\end{array}$ & $\mathrm{k}$ \\
\hline rude & $\mathrm{d}$ & rudzi & dź & drudzy, drodzy & $\begin{array}{c}\mathrm{dz} \\
\text { (d)ż }\end{array}$ & $\begin{array}{l}\text { drugie, } \\
\text { drogie }\end{array}$ & $\mathrm{g}$ \\
\hline łyse & $\mathrm{s}$ & $\begin{array}{r}\text { łysi } \\
\text { malusie: malusi } \\
\text { nasi pierwsi } \\
\text { lepsi }\end{array}$ & $\dot{s}$ & $\begin{array}{r}\text { nasze pierwsze lepsze } \\
\text { głusi }\end{array}$ & $\mathrm{sz}$ & głuche & $\mathrm{ch}$ \\
\hline & $\mathrm{z}$ & duzi & $\dot{z}$ & duże & $\dot{\mathrm{z}}$ & & \\
\hline $\begin{array}{r}\text { silne } \\
\text { pieszczone } \\
\text { inne } \\
\text { one, jedne }\end{array}$ & $\mathrm{n}$ & $\begin{array}{r}\text { silni } \\
\text { pieszczeni } \\
\text { inni } \\
\text { oni, jedni } \\
\text { tanie : tani }\end{array}$ & ń & & & & \\
\hline stare, które & $\mathrm{r}$ & & & starzy, którzy & $\mathrm{rz}$ & & \\
\hline $\begin{array}{r}\text { małe } \\
\text { złe } \\
\text { wesołe }\end{array}$ & 1 & $\begin{array}{r}\text { mali } \\
\text { źli } \\
\text { weseli }\end{array}$ & 1 & & & & \\
\hline
\end{tabular}

Źródło: opracowanie własne

W zestawie deklinabiliów, określających rzeczowniki w liczbie mnogiej, do niektórych pozycji trudno znaleźć przykłady (stąd puste okna tabeli), jednak nie ograniczono tu zestawu spółgłosek. Chodzi nam głównie o utrwalanie schematów, pozwalających na prezentację alternacji jako jednolitego systemu, wspólnego dla polskich procesów morfonologicznych. Jeśli student raz zrozumie, jak to 
funkcjonuje, będzie mu o wiele łatwiej przyswajać nowe kategorie gramatyczne czy polubić szeregi alternacyjne, jak na przykład noga na nodze, nóżka na nózi; miasto, a w mieście sami mieszczanie; kwas jest kwaśny czy kwaszony?

\section{PARALELE MIĘDZY FLEKSJĄ, STOPNIOWANIEM A SLOWOTWÓRSTWEM}

Część druga, Alternacje morfonologiczne w koniugacji, pokazuje, w których osobach gramatycznych (w którym miejscu w paradygmacie odmiany) mogą wystąpić oboczności w tematach fleksyjnych czasowników. Ucząc języka polskiego, warto też pokazywać, jakich wymian morfonologicznych można się spodziewać; dla polszczyzny charakterystyczne są paralele alternacyjne między koniugacją a deklinacją czy stopniowaniem, por.: Przy ładnej pogodzie wreszcie mogę pojechać na rowerze nad jezioro, biorę więc ze soba Jasia, pojedziemy popływać; będę się cieszyć, jak pogadamy po drodze. To samo inaczej: Jest ładna pogoda, więc jadę rowerem poptywać w jeziorze, może Jachu się ze mna zabierze; będzie dhuga rozmowa, jak wybierzemy dtuższa drogę. Już w powyższym przykładzie charakterystyczne podobieństwa, jak alternacje $d: d \dot{z}, r: r z, g: \dot{z}$. Nie zajmujemy się tu obocznościami samogłoskowymi, gdyż nie dają się one tak łatwo uporządkować, jak spółgłoskowe - wielu z nich trzeba się nauczyć na pamięć, pojawiają się one głównie w wyrazach rodzimych i na szczęście nie są częste.

Zamiast dalszych komentarzy na temat reguł gramatycznych przygotowano ćwiczenie, które można zaproponować studentom na stosunkowo wczesnym etapie nauki. W tekście Róże dla siostry należy wyszukać czasowniki w czasie teraźniejszym oraz przyszłym dokonanym, a następnie wpisać 1 . i 2 . osobę liczby pojedynczej tych czasowników do odpowiednio przygotowanej tabeli; o miejscu $\mathrm{w}$ tabeli decyduje wygłos $\mathrm{w}$ temacie fleksyjnym. Zgromadzono tu czasowniki, które należą do grup -ę, -esz oraz -e, -isz. ${ }^{6}$

Kiedy pojadę do siostry, zawioze jej kwiaty. Zawsze wożę siostrze kwiaty, kiedy do niej jeżdżę, bardzo to lubię. Zetniesz mi dla niej ładne róże? Zerwiesz nam jakieś jabluszka? Na pewno znajdziesz w ogrodzie. Zrobisz to dla mnie, proszę? Ja się tymczasem spokojnie przebiorę. Sama nie mogę iść do ogrodu, bo jeszcze

${ }^{6}$ Jak wspomniano, w grupie -ę, -ysz alternacje nie występują, a jeśli pierwsza osoba jest zakończona na $-m$, to tylko kilka czasowników ma nietypową odmianę (-dzq zamiast -ja w trzeciej osobie liczby mnogiej), trzeba się ich więc nauczyć na pamięć. W czasownikach typu kroję : kroisz, boję : boisz ze względu na zasady ortograficzne w środku paradygmatu odmiany (2. i 3. os. lp oraz 1. i 2. os. lmn.) nie wpisujemy joty. Alternacje samogłoskowe mogą wystąpić w trybie rozkazującym, por. Bój się Boga, nie krój ryby nożem! 
się pobrudzę, podrę sobie rajstopy albo pogniotę tę nowa sukienkę. A polecisz szybko po jakiś wazon? Może tym razem nie stluczesz. Sam widzisz, że już późno! Boję się, że zamkna sklep, więc musisz mi pomóc. A może wyczyścisz mi te nowe buty? Ja za to kupię ci dobre winko, jak wrócę.

Tabela 11. Alternacje w odmianie czasowników, czas teraźniejszy i przyszły dokonany

\begin{tabular}{|c|c|c|c|c|c|c|c|}
\hline \multicolumn{2}{|c|}{ A. Język z przodu } & \multicolumn{3}{|c|}{ B. Język wygięty ku palatum } & & \multicolumn{2}{|c|}{ C. Język z tyłu } \\
\hline \multicolumn{8}{|c|}{ Kierunek zmian w położeniu języka przy zmianie 1 . os. liczby poj. na 2. os. liczby poj. } \\
\hline \multicolumn{4}{|c|}{ 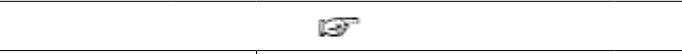 } & \multicolumn{4}{|c|}{ छ } \\
\hline \multicolumn{2}{|l|}{ ja } & \multicolumn{2}{|l|}{ ja: ty } & \multicolumn{4}{|c|}{ ja } \\
\hline zajmę & $\begin{array}{l}\mathrm{p} \\
\mathrm{b} \\
\mathrm{m}\end{array}$ & $\begin{array}{r}\text { kupię : kupisz } \\
\text { lubię : lubisz } \\
\text { zajmiesz }\end{array}$ & $\begin{array}{l}\mathrm{pj} \\
\mathrm{bj} \\
\mathrm{mj}\end{array}$ & & & & \\
\hline zerwę & $\begin{array}{l}\mathrm{f} \\
\mathrm{w}\end{array}$ & $\begin{array}{r}\text { zerwiesz } \\
\text { mówię : mówisz }\end{array}$ & $\begin{array}{l}\mathrm{fj} \\
\mathrm{wj}\end{array}$ & & & & \\
\hline pogniotę & $\mathrm{t}$ & $\begin{array}{r}\text { pognieciesz } \\
\text { polecisz } \\
\text { wrócisz }\end{array}$ & ć & $\begin{array}{r}\text { polecę } \\
\text { wrócę } \\
\text { sttuczesz }\end{array}$ & $\mathrm{cz}$ & stłukę & $\mathrm{k}$ \\
\hline $\begin{array}{l}\text { znajdę } \\
\text { pojadę }\end{array}$ & $\mathrm{d}$ & $\begin{array}{r}\text { pobrudzisz } \\
\text { widzisz } \\
\text { znajdziesz } \\
\text { pojedziesz } \\
\text { jeździsz }\end{array}$ & dź & $\begin{array}{r}\text { pobrudzę } \\
\text { widzę } \\
\\
\text { jeżdżę } \\
\text { możesz } \\
\end{array}$ & $\begin{array}{c}\mathrm{dz} \\
\text { (d) } \dot{\mathrm{z}}\end{array}$ & mogę & $\mathrm{g}$ \\
\hline przyniosę & $\mathrm{s}$ & $\begin{array}{r}\text { przyniesiesz } \\
\text { prosisz } \\
\text { musisz }\end{array}$ & ś & $\begin{array}{l}\text { proszę } \\
\text { muszę }\end{array}$ & sz & & $\mathrm{ch}$ \\
\hline zawiozę & $\mathrm{z}$ & $\begin{array}{r}\text { wozisz } \\
\text { zawieziesz }\end{array}$ & ź & wożę & $\dot{\mathrm{z}}$ & & \\
\hline $\begin{array}{r}\text { zetnę } \\
\text { zamknę }\end{array}$ & $\mathrm{n}$ & \begin{tabular}{r|} 
zetniesz \\
zamkniesz
\end{tabular} & ń & & & & \\
\hline $\begin{array}{r}\text { przebiorę } \\
\text { podrę }\end{array}$ & $\mathrm{r}$ & & & $\begin{array}{l}\text { przebierzesz } \\
\text { podrzesz }\end{array}$ & $\mathrm{rz}$ & & \\
\hline
\end{tabular}

Źródło: opracowanie własne

Jak widać, formy podstawowe (ja) zajmują obrzeża tabeli, natomiast formy zależne (ty), zaznaczone kursywą, znajdziemy w jej środku. Podobnie jak w innych deklinabiliach czasowniki miękkotematowe nie podlegają alternacjom.

W wielu podręcznikach wspomagających naukę polskiego jako obcego znajdziemy podstawowe informacje z dziedziny słowotwórstwa; stosunkowo dobrze 
są opracowane takie tematy, jak zdrobnienia czy tworzenie nazw żeńskich. Tu ograniczymy się do wskazania możliwości wzbogacania zasobu leksykalnego polszczyzny przez wyrażenia syntaktyczne typu za Kaukazem : Zakaukazie, co pozwoli na skrótowe porównanie procesów alternacyjnych między fleksją a słowotwórstwem.

W poniższej tabeli podane są głównie toponimiczne wyrażenia syntaktyczne oraz terminologia medyczna. Zadaniem studentów jest odnalezienie form, od których pochodzą te nazwy oraz określenie, z jakimi alternacjami mamy tu do czynienia. Nazwy geograficzne to głównie starsza część leksykonu, palatalizujący morfem słowotwórczy -e może więc pociągać za sobą głębsze alternacje, por. las $\rightarrow$ Polesie.

Tabela 12. Wybrane przykłady alternacji morfonologicznych z dziedziny słowotwórstwa

\begin{tabular}{|c|c|c|c|c|c|c|c|c|c|}
\hline \multicolumn{4}{|c|}{ A. Język z przodu } & \multicolumn{4}{|c|}{$\begin{array}{l}\text { B. Grzbiet lub czubek języka blisko } \\
\text { środka, wygięty ku palatum }\end{array}$} & \multicolumn{2}{|c|}{ C. Język z tyłu } \\
\hline & I & & II & & III & & IV & & $\mathbf{V}$ \\
\hline płaskostopie & $\mathrm{p}$ & Podkarpacie & $\mathrm{t}$ & & ć & Zaplecze & $\begin{array}{l}\mathrm{c} \\
\mathrm{cz}\end{array}$ & $\begin{array}{r}\text { pobocze } \\
\text { osocze }\end{array}$ & $\mathrm{k}$ \\
\hline $\begin{array}{r}\text { podglebie } \\
\text { bezrybie }\end{array}$ & $\mathrm{b}$ & $\begin{array}{r}\text { śródlądzie } \\
\text { podudzie }\end{array}$ & $\mathrm{d}$ & & dź & & $\begin{array}{c}\mathrm{dz} \\
\text { (d) } \dot{\mathrm{z}}\end{array}$ & $\begin{array}{l}\text { wybrzeże } \\
\text { śródmóżdże }\end{array}$ & $\mathrm{g}$ \\
\hline & $\mathrm{f}$ & Polesie & $\mathrm{s}$ & śródpiersie & ś & & sz & poddasze & $\mathrm{ch}$ \\
\hline pogłowie & $\mathrm{w}$ & Zaolzie & $\mathrm{z}$ & & ź & & $\dot{\mathrm{z}}$ & & \\
\hline przedbramie & $\mathrm{m}$ & przedwiośnie & $\mathrm{n}$ & & ń & & & & \\
\hline & & Podgórze & $\mathrm{r}$ & & & Przymorze & $\mathrm{rz}$ & & \\
\hline & & przedszkole & 1 & Zapole & 1 & & & & \\
\hline
\end{tabular}

Źródło: opracowanie własne

Już na pierwszy rzut oka widać, iż mamy tu do czynienia z podobnymi alternacjami, jakie charakteryzują też polską fleksję.

Palatalizacje morfonologiczne można omawiać przy okazji poznawania nazw zwierząt; przymiotniki zoonimiczne tworzą popularne frazy typu matpi gaj, krowie mleko, kocia muzyka, psia buda, kozi ser, bocianie gniazdo, sokoli wzrok, kurze jaja, łabędzi śpiew, gęsie pióro, koński ogon, krokodyle tzy, mysia dziura, bycza krew, zajęcza warga, pajęcza sieć, waga musza. Wszystkie te przykłady pasują do proponowanego tu sposobu nauczania alternacji morfonologicznych: rzeczowniki miękkotematowe zamieniamy na przymiotniki bez większych zmian, natomiast rzeczowniki twardotematowe ulegają typowym obocznościom.

Podobne procesy zauważymy też w czasownikach odrzeczownikowych, por. Adam się ślimaczy, Ewa się byczy, dziecko raczkuje, dziadek się indyczy; do ćwiczeń polecamy bezkonkurencyjny Figielek Tuwima. 
Przykłady zebrane w niniejszym artykule ilustrują przede wszystkim paralele między alternacjami w odmianie czasowników, rzeczowników, przymiotników, imiesłowów, liczebników i zaimków w polszczyźnie. Nie można wykluczyć, iż liczne zdrobnienia pojawiające się w języku, jakim mówimy do dzieci, mają między innymi na celu oswajanie ich z alternacjami. Typowymi wyrazami i zwrotami mowy matczynej (ang. motherese) da się bez problemu wypełnić tabele ze schematami do ćwiczeń alternacji, por. oko : oczko, ucho : uszko, noga : nóżka : nózia, but : bucik, trochę : troszkę : troszeczkę itp. Zdrobnienia możemy też budować ad hoc, por. nie płakuchnaj, kochanieńku, biedny nosiu przestanie boleć bez problemu zrekonstruujemy jako nie płacz, kochanie, biedny nosek przestanie boleć. Deminutywa, w porównaniu z angielskim czy niemieckim, mają w języku polskim bardzo dużą frekwencję, da się je też tworzyć na wiele sposobów. W słowotwórstwie generalnie trudno mówić o ścisłych regułach (por. dywan: dywanik, ale batwan: batwanek; koń: konik, ale jeleń : jelonek), jednak tendencja do alternacji jest w polszczyźnie bardzo wyraźna.

\section{PODSUMOWANIE}

W niniejszym artykule próbowano wykazać, iż bogatym światem polskich alternacji rządzą stosunkowo proste reguly, które warto systematycznie ćwiczyć ze studentami od początku nauki. Przy takim podejściu liczne formy gramatyczne nie jawią się jako ocean wyjątków, lecz jako solidny pień, do którego możemy dodawać coraz to nowe gałęzie. Uproszczenia w podejściu teoretycznym oraz w terminologii były tu nie do uniknięcia, bez nich artykuł rozrósłby się niepomiernie.

W opracowaniach poświęconych nauczaniu polskiego jako obcego omawiane tu zagadnienia są traktowane po macoszemu. Z perspektywy dydaktycznej chyba najlepszy zestaw alternacji znajdziemy w Przygodzie z gramatyka (Pyzik 2000), lecz podręcznik ten opisuje polskie przypadki gramatyczne po kolei, nie podkreślając wspólnoty procesów morfonologicznych, które ciągną się przez całą gramatykę. Te same procesy widzimy w deklinacji, w koniugacji, w stopniowaniu, a także w dużych obszarach słowotwórstwa - niestety trudno znaleźć prace glottodydaktyczne, podkreślające takie paralele, mimo iż od dawna istnieją monografie poświęcone polskiej morfonologii (por. np. Laskowski 1975 czy Kowalik 1997).

Alternacje będące przedmiotem analizy w niniejszym artykule są obligatoryjne; nie należą one do rzadkich konstrukcji. Schematyczny indeks a tergo polskich form wyrazowych (Tokarski 1993), notuje około 500 leksemów, realizujących alternacje typu grafik : graficy, 450 leksemów typu pilot : piloci, a dodatkowo około 1000 leksemów w grupie na -a, typu atleta : atleci. W koniugacji sama oboczność $s z: s ́$ (por. ja noszę : ty nosisz) obejmuje ponad 250 czasowników. 
Liczne są także alternacje w przymiotnikach czy imiesłowach; około 900 leksemów podlega alternacjom typu słabszy : słabsi. Przymiotników odrzeczownikowych, w których mamy wymianę $k: c z$, jak huk: huczny, odnotowano około 2450 razy. Pozostawianie tego tematu poza obszarem glottodydaktyki utrudnia uczenie (się) polszczyzny.

\section{BIBLIOGRAFIA}

Bańko M., Komosińska, D., Stankiewicz, A., 2003, Indeks a tergo do Uniwersalnego stownika języka polskiego, Warszawa.

Bisko A., 2014, Polska dla średniozaawansowanych. Wspótczesna polskość codzienna, Kraków.

Engel, U., 2000, Deutsch-polnische kontrastive Grammatik, Warszawa.

Grochala B., 2016, Metajęzyk w wybranych podręcznikach do nauczania języka polskiego jako obcego, „Acta Universitatis Lodziensis. Kształcenie Polonistyczne Cudzoziemców”, t. 23, G. Zarzycka, M. Biernacka, (red.), s. 73-82. http://dx.doi.org/10.18778/0860-6587.23.06

Karasek M., Gaze M., 2019, Świadomość lingwistyczna (przyszłych) lektorów języka polskiego jako obcego - kilka uwag o znajomości fleksji imiennej, „Acta Universitatis Lodziensis. Kształcenie Polonistyczne Cudzoziemców”, t. 26, G. Zarzycka, B. Grochala, I. Dembowska-Wosik (red.), s. 139-148. http:dx.doi.org/10.18778/0860-6587.26.08

Kowalik K., 1997, Struktura morfonologiczna wspótczesnej polszczyzny, Kraków.

Laskowski R., 1975, Studia nad morfonologia współczesnego języka polskiego, Wrocław.

Madelska L., 2005, Stownik wariantywności fonetycznej współczesnej polszczyzny, Kraków.

Madelska L., 2007, Polnisch entdecken, Kraków.

Madelska L., 2008, Praxis-Grammatik Polnisch, Poznań.

Madelska L., 2009, Polski na tle języków świata a nauczanie wymowy w glottodydaktyce, „Poradnik Językowy" z. 6 (665), s. 38-55.

Madelska L., 2010, Postuchaj, jak mówię. Podręcznik ucznia; Poradnik dla rodziców i nauczycieli; film dydaktyczny Powiedz mi, co widzisz, Wiedeń.

Madelska L., 2012, Prakticzeskaja grammatika polskogo jazyka, Kraków.

Madelska L., Schwartz, G., 2010, Discovering Polish. A Learner's Grammar, Kraków.

Madelska L., Warchoł-Schlottmann, M., 2008, Odkrywamy język polski. Gramatyka dla uczacych (się) języka polskiego jako obcego, Kraków.

Orbitowski Ł., 2019, Kult, Warszawa.

Pałuszyńska E., 2019, Kategoria rodzaju gramatycznego w systemie językowym, dyskursie i glottodydaktyce, „Acta Universitatis Lodziensis. Kształcenie Polonistyczne Cudzoziemców”, t. 26, G. Zarzycka, B. Grochala, I. Dembowska-Wosik (red.), s. 413-424. http:dx.doi. org/10.18778/0860-6587.26.28

Perlin J., 2013, O potrzebie, a nawet konieczności uwzględnienia infiksów w opisie polskiej fleksji werbalnej, „Linguistica Copernicana” 1 (9), s. 203-213.

Pyzik J., 2000, Przygoda z gramatyką. Fleksja i słowotwórstwo imion, Kraków.

Tokarski J., 1993, Schematyczny indeks a tergo polskich form wyrazowych, Warszawa. https:// pl.wiktionary.org/wiki/Kategoria:polski_(indeks_a_tergo), [30.05.2020].

Wicherkiewicz W., 1911, Polnische Konversations-Grammatik, Heidelberg. 


\section{Liliana Madelska}

\section{OLD PILOTS ON THE BRIDGE, THAT IS THE DISCREET CHARM OF THE ALTERNATIONS}

Keywords: Polish as a foreign language, morphonological alternations, flexion, word formation, glottodidactic awareness

Abstract. Polish is wrongly regarded as a particularly difficult language. Morphonological alternations that occur in verbs, nouns, adjectives, numerals, pronouns and participles, in gradation, as well as in word-formation, seem to be difficult, indeed. This article demonstrates that a few simple rules suffice to organise the seemingly chaotic world of Polish alterations. When teaching Polish as a foreign language, it is worth introducing these rules step by step from the initial stage of learning. Furthermore, properly presented examples can be more instructive than lengthy metalinguistic comments. With this approach, numerous grammatical forms do not appear to be an ocean of exceptions, but a network of waterways that can be navigated safely. 